\title{
Update on Some Aspects of Neonatal Thyroid Disease
}

\author{
Tamar Simpser ${ }^{1}$, Robert Rapaport1 \\ ${ }^{1}$ Mount Sinai School of Medicine, Pediatric Endocrinology, New York, NY, USA
}

\begin{abstract}
This article explores the basic development and pathophysiology of the thyroid gland. New factors in the normal development of the thyroid in the neonate are mentioned. The incidence of congenital hypothyroidism continues to increase. We describe congenital hypothyroidism, its possible etiologies, treatment and outcomes. We explore hypothyroxinanemia in pre-term neonates and the risk/benefit of prophylactic thyroid hormone replacement. We discuss the late rise of thyrotropin (TSH) in ill infants and those with very low birth weight. III infants or those born premature should have their thyroid function tests routinely monitored. On the occasion of borderline thyroid function test results, TRH testing can be useful in identifying those infants with either persistent or transient hypothyroidism. TRH testing is also helpful in identifying those patients with secondary hypothyroidism. With the early identification and prompt and proper treatment, neonates with congenital hypothyroidism, transient or persistent, should have positive long-term outcomes.

Key words: Congenital hypothyroidism, thyroxine
\end{abstract}

Conflict of interest: None declared

Received: 08.062010

Accepted: 07.07.2010

\section{Introduction}

Goiter was first described between the years 2838-2698 B.C.E in the book Pen-Ts'ao Tsing (A Treatise on Herbs and Roots). The supposed author, emperor Shen-Nung, recommended the seaweed Sargassum as an effective remedy for goiter (1). It was not until the $1^{\text {st }}$ century B.C.E. that the writings of Roman authors Vitruvius, Pliny the Elder and Juvenal, made reference to endemic goiter in a region of the Alps. Although already recognized as a medical condition, congenital hypothyroidism was not mentioned in medical texts until year 1300 by Arnaldus de Villanova (goitres in Lucca) and Lanfrancus (goitres in Lombardy) (2). There have been many advances in the study of congenital hypothyroidism since then, most notably in the past forty years.

Normal thyroid function is essential for the growth and neurodevelopment of infants and young children. Abnormalities of thyroid gland development, migration and function can all lead to congenital hypothyroidism. Recent reviews have included defects in the sodium-iodide transporter and the thyrotropin (TSH) receptor, as well as the transcription factors (TFs) PAX-8, TTF1, TTF2 and others, all of which may be associated with abnormalities in thyroid function.

The development of the normal fetal-neonatal thyroid system can be categorized in three phases. The first one begins with thyroid and pituitary embryogenesis occurring up to the $10^{\text {th }}-12^{\text {th }}$ weeks of gestation. The histologic and functional maturation of the hypothalamus and of the pituitary portal vascular systems begins at $4^{\text {th }}-5^{\text {th }}$ gestational weeks and continues through gestational weeks 30-35. The third and final phase of fetal thyroid development is the maturation of the hypothalamic-pituitary-thyroid axis beginning at mid-gestation and continuing through to approximately 4 weeks postnatally. One can easily infer that infants born

Address for Correspondence

Tamar Simpser, Mount Sinai School of Medicine, Pediatric Endocrinology, New York, NY, USA Phone: +1 2122416936

E-mail: tamar.simpser@gmail.com

@ Journal of Clinical Research in Pediatric Endocrinology, Published by Galenos Publishing. 
before term may have disruption in the normal maturation of the fetal hypothalamic-pituitary-thyroid axis leading to abnormal thyroid function.

Genetic defects in transcription factors have been described in relatively few patients. There is great variability between genotype and phenotype in affected individuals. For example, the same defect in PAX 8 may result in anywhere from a normal to an absent thyroid gland and from euthyroidism to severe hypothyroidism $(3,4,5,6,7,8)$ (Table 1). Some of the TFs involved in thyroid gland development are also involved in the development of other tissues, such as the kidneys and lungs. There is an increased odds ratio of 13.2 for having renal and urinary tract abnormalities in children with congenital hypothyroidism versus children without congenital hypothyroidism (9). For further details of thyroid gland development, several reviews are recommended $(10,11,12)$.

Thyroid function of the neonate can be affected by the mother's thyroid status by way of placental transfer. While $\mathrm{TSH}$ is not transferred from the mother, small amounts of thyroxine (T4) and triiodothyronine (T3) do cross the placental barrier. Thyroid antibodies, both stimulatory and inhibitory, as well as anti-thyroid medication easily cross the placenta and are transferred from the mother to the fetus. For example, the thyroid stimulating immunoglobulins (TSI) from a mother with Graves disease will cross the placental barrier and can result in transient hyperthyroidism in the neonate. If this same mother is on treatment with thioamides, which also cross the placental barrier, the neonate can develop transient hypothyroidism. The possible impact of the mother's thyroid status could present a difficult challenge to the physician in diagnosing thyroid abnormalities in the neonate. We have recommended measurements of TSI in such newborns as helpful in assessing the likelihood of developing symptomatic hyperthyroidism (13).
Results of thyroid function tests (TFTs) vary with age. There is a rise in TSH, T3 and T4 immediately after birth. These measures of thyroid function will gradually decrease by 3-4 days of age. It is important to note that specimens obtained on the first day of life might have a high TSH level with high levels of T3 and T4. TFTs in babies born prior to term need to be interpreted with careful regard for age and gestational age. T4 and T3 are especially affected. TSH levels do not vary as greatly during the newborn period.

If neonates with congenital hypothyroidism are left untreated, they will develop severe symptoms of hypothyroidism, such as developmental and growth retardation. In order to avoid potential damage to the developing brain caused by congenital hypothyroidism, newborn screening was instituted in Quebec, Canada in 1974. The frequency of congenital hypothyroidism was found to be $1: 7000$ and the screening program was continued (14). With the expansion of newborn screening programs, the frequency of congenital hypothyroidism continues to increase in the United States (US) and worldwide and is now thought to be around 1:3000-4000. In New York State alone, between 1978 and 2005, the incidence of congenital hypothyroidism has increased by $138 \%$ to approximately 1:1415 births. In the US (excluding New York State data), with nearly 58 million infants screened between 1987 and 2002, the incidence has increased $73 \%$ (15). The largest proportion of newborn screening programs worldwide and in the US use a primary T4 screen with TSH measured to confirm the lowest T4 results. Other countries and fewer US states use a primary TSH screen alone. In the US, a limited number of states perform both a primary T4 and TSH screen at the initial screening $(16,17)$.

It is important to note that two-thirds of infants diagnosed with congenital hypothyroidism had neither signs nor

Table 1. Genetic mutations and variant phenotypes

\begin{tabular}{|c|c|c|c|}
\hline Variation & Phenotype & Function & Reference \\
\hline \multicolumn{4}{|l|}{ PAX8: } \\
\hline \multirow[t]{3}{*}{ T225M } & Normal size & Euthyroid & Tonacchera et al (4) \\
\hline & Ectopia & Mild hypothyroidism & \\
\hline & Hypoplasia & Severe hypothyroidism & \\
\hline \multicolumn{4}{|l|}{ TTF-1: } \\
\hline \multirow[t]{2}{*}{ Whole gene deletion } & Normal size & Mild hypothyroidism & Iwatani et al (5) \\
\hline & Hypoplasia & Severe hypothyroidism & Krude et al (6) \\
\hline \multicolumn{4}{|l|}{ TTF-2/FOXE1 } \\
\hline \multirow[t]{2}{*}{ Missense mutations } & Athyreosis & Hypothyroidism & Castanet et al (7) \\
\hline & Hypoplasia & Severe hypothyroidism & Baris et al (8) \\
\hline
\end{tabular}


symptoms of hypothyroidism. Transient hypothyroxinemia is common in neonates born prematurely. Thyroxine-binding globulin (TBG) deficiencies occur in 1:9000, while TSH and/or TRH deficiencies occur in less than 1:20000-100000. A study in the Netherlands that screened 385000 infants over a two-year period found that congenital hypothyroidism of central origin occurs more often than previously thought. They reported an incidence of 1:20000, representing 13.5\% of all cases of permanent congenital hypothyroidism. Over three quarters of the permanent cases of congenital central hypothyroidism had multiple pituitary hormone deficiency and half had pituitary malformations (18).

Treatment for congenital hypothyroidism is thyroid hormone replacement. The current recommended dose is $10-15 \mu \mathrm{g} / \mathrm{kg} /$ day of thyroxine, to be given orally as crushed tablets. Treatment should be instituted as early as possible, in order to optimize cognitive and physical development. Most children do well with treatment, and higher initial thyroxine dosage combined with shorter time to normalization contribute to improved developmental outcome $(19,20)$.

Some suggest that the dose of thyroid hormone required may be directly related to the etiology of the hypothyroidism. Infants with athyreosis require a higher dose than those with dysgenesis, who require a higher dose than those with dyshormonogenesis (21). Contrary to previous beliefs, congenital hypothyroidism, even due to thyroid dysgenesis, may not be a random occurrence. In a 2001 review of 19 years of newborn screening in France, Castanet et al (22) found that familial cases were reported in a high proportion of children with thyroid dysgenesis, suggesting the possibility of a genetic component. A further review in 2010 by Castanet et al (23) estimates the prevalence of familial cases of thyroid dysgenesis at $2 \%$.

Treatment with thyroid hormone has generally been quite safe and effective. In young adults diagnosed through the national neonatal screening program in the Netherlands, it was found that in neonates with severe congenital hypothyroidism,cognitive and motor defects persist through young adult life. The median age of start of treatment was 28 days after birth and was not an important factor in determining long-term cognitive and motor outcome. The study concludes that the severity of congenital hypothyroidism is inversely correlated with $\mathrm{IQ}$ and motor scores (24). Impaired diastolic function and exercise capacity in young adults treated with levothyroxine for congenital hypothyroidism has also been reported. Compared with controls, hypothyroid patients exhibited a higher frequency of left ventricular diastolic dysfunction, impaired exercise capacity, and increased intima-media thickness. Close monitoring of thyroid hormone replacement therapy can prevent cardiovascular abnormalities related to episodes of subclinical hypothyroidism and hyperthyroidism (25).
In neonates with an initial abnormal screen accompanied by normal serum T3 and T4 levels and only mildly elevated $\mathrm{TSH}$, one is faced with a conundrum of mild abnormalities. Based on a 1993 study, we recommended thyroid releasing hormone (TRH) testing for children who had mildly elevated baseline TSH values in order to identify those infants in whom thyroid hormone replacement may be needed, even if transiently (26). This approach was substantiated in an article by Daliva et al (27) who showed that 13 of 14 children with borderline TSH levels at screening had thyroid function anomalies that persisted at three years of age. Of those 13 children, three underwent TRH testing, with two exhibiting hyper-responsiveness (>35mU/L) $(27,28)$. Recent studies have shown that certain genetic defects can result in either mild or transient hypothyroidism $(29,30,31)$ (Table 2). Therefore, $\mathrm{TRH}$ testing should be recommended to identify cases of mild congenital hypothyroidism. In addition, TRH testing has a role in diagnosing central hypothyroidism and isolated TSH deficiency (32).

A common finding in preterm newborns is neonatal hypothyroxinemia. Neonatal hypothyroxinemia has been associated with cerebral palsy, mortality, morbidity, and intraventricular hemorrhage (33,34). Attempts have been made to replace T4 in premature infants with limited demonstrable results $(35,36,37)$. In 2001, we recommended that hypothyroxinemia of the preterm infant should not be routinely treated in Neonatal Intensive Care Units, unless aspart of an ongoing study (38). In 2007, a Chochrane Database Systematic Review also did not support the use of prophylactic thyroid hormones in preterm infants to reduce neonatal mortality, neonatal morbidity or improve neurodevelopmental outcomes (39). Prospective studies of thyroid hormone supplementation in premature neonates are underway (40).

Late rise in TSH (LRT) is defined as an elevated TSH level following a normal TSH on the initial newborn screen, with either a normal or a low T4. LRT can occur in premature or ill infants and babies with very low birth weight. We have recommended routine monitoring of TFTs in ill newborns (41). Possible causes of LRT are developmental delays in the maturation of the hypothalamic-pituitary-thyroid axis, exposure to medications and antiseptics, and recovery from sick euthyroid syndrome. A one-year study found 14 infants who had late rise in TSH. Nearly half the cases $(n=6)$ resolved spontaneously, while the remaining 8 infants required thyroid hormone replacement. Of these 14 infants, $79 \%$ were premature and 7 had very low birth weight (VLBW). Ten of these infants underwent surgery and of those, 6 had elevated urine iodine. We concluded that LRT in ill newborns may be a common finding and not necessarily associated with birth weight (42). 
Abnormalities of thyroid function tests are common in newborns. Particular attention should be paid to recognizing specific disorders of the thyroid gland. It is imperative that any thyroid function abnormalities be identified and treated

\begin{tabular}{|c|c|}
\hline Variation & Function \\
\hline \multicolumn{2}{|l|}{ DU0X231: } \\
\hline $\begin{array}{l}\text { Heterozygous: } \\
\text { c.1435_1440delCTATCCinsAG }\end{array}$ & Euthyroid \\
\hline $\begin{array}{l}\text { Heterozygous: } \\
\text { c.1883delA }\end{array}$ & Euthyroid \\
\hline Coumpound Heterozygous: & Transient CH \\
\hline $\begin{array}{l}\text { c.1435_1440delCTATCCinsAG } \\
\text { and c.1883delA }\end{array}$ & $\begin{array}{l}\text { Transient } \\
\text { hyperthyrotropinemia }\end{array}$ \\
\hline $\begin{array}{l}\text { Heterozygous: } \\
\text { c.1588A-->T;3200T-->C }\end{array}$ & Euthyroid \\
\hline $\begin{array}{l}\text { Heterozygous: } \\
\text { c.2635G-->A;3200T-->C }\end{array}$ & Euthyroid \\
\hline $\begin{array}{l}\text { Compound Heterozygous: } \\
\text { c.1588A-->T;3200T-->C and } \\
\text { c.2635G-->A;3200T-->C }\end{array}$ & Transient CH \\
\hline $\begin{array}{l}\text { Heterozygous: } \\
\text { c.2033A-->G }\end{array}$ & Euthyroid \\
\hline $\begin{array}{l}\text { Heterozygous: } \\
\text { c.3200T-->C }\end{array}$ & Euthyroid \\
\hline $\begin{array}{l}\text { Compound Heterozygous: } \\
\text { c.2033A-->G and } \\
\text { c.3200T-->C }\end{array}$ & Transient $\mathrm{CH}$ \\
\hline тHОX232: & \\
\hline Homozygous: C1300T & Permanent $\mathrm{CH}$ \\
\hline Heterozygous: C1300T & Euthyroid \\
\hline Heterozygous: C2056T & $\begin{array}{l}\text { Transient CH } \\
\text { Euthyroid }\end{array}$ \\
\hline C2101T & $\begin{array}{l}\text { Transient } \mathrm{CH} \\
\text { T4 screening }-0.6 \mathrm{SD} \\
\text { Euthyroid }\end{array}$ \\
\hline 2895-2898del & $\begin{array}{l}\text { Transient CH } \\
\text { Euthyroid }\end{array}$ \\
\hline
\end{tabular}

as early as possible to ensure the best neurodevelopmental and growth outcomes. Genetic studies have already helped to identify the etiology of congenital hypothyroidism in some infants. Expanded genetic screening is likely to be more available in the near future.

\section{References}

1. Langer P. History of goiter. In: Endemic Goitre, WHO Monograph Series. Geneva, 1960;9-25.

2. F. Merke. The History of Endemic Goitre and Cretinism in the Thirteenth to Fifteenth Centuries. Proc R Soc Med. 1960;53:995-1002. [Full Text]

3. Montanelli L, Tonacchera M. Genetics and phenomics of hypothyroidism and thyroid dys- and agenesis due to PAX8 and TTF1 mutations. Mol Cell Endocrinol. 2010;30:64-71. [Abstract] / [Full Text] / [PDF]

4. Tonacchera M, Banco M.E., Montanelli L, Di Cosmo C, Agretti P, De Marco G, Ferrarini E, Ordookhani A, Perri A, Chiovato L, Santini F, Vitti P, Pinchera A. Genetic analysis of the PAX8 gene in children with congenital hypothyroidism and dysgenetic or eutopic thyroid glands: identification of a novel sequence variant. Clin Endocrinol. 2007;67:34-40. [Abstract] / [PDF]

5. Iwatani N, Mabe H, Devriendt K, Kodama M, Miike T. Deletion of NKX2-1 gene encoding thyroid transcription factor-1 in two siblings with hypothyroidism and respiratory failure. J Pediatr. 2000;137:272-276. [Abstract] / [Full Text] / [PDF]

6. Krude H, Schütz B, Biebermann H, vonMoers A, Schnabel D, Neitzel H, Tönnies H, Weise D, Lafferty A, Schwarz S, De Felice M, von Deimling A, van Landeghem F, Di Lauro R, Grüters A. Choreoathetosis, hypothyroidism, and pulmonary alterations due to human NKX2-1 haploinsufficiency. Clin Invest. 2002;109:475-480. [Abstract] / [Full Text] / [PDF]

7. Castanet $M$, Park SM, Smith A, Bost M, Léger J, Lyonnet $S$, Pelet A, Czernichow P, Chatteriee K, Polak M. A novel lossof-function mutation in TTF-2 is associated with congenital hypothyroidism, thyroid agenesis, and cleft palate. Hum Mol Genet 2002;11:2051-2059. [Abstract] / [PDF]

8. Baris I, Arisoy AE, Smith A, Agostini M, Mitchell CS, Park SM, Halefoglu AM, Zengin E, Chatteriee VK, Battaloglu E. A novel missense mutation in human TTF-2 (FKHL15) gene associated with congenital hypothyroidism but not athvreosis. J Clin Endocrinol Metab. 2006:91:4183-4187. [Abstract] / [PDF]

9. Kumar J, Gordillo R, Kaskel FJ, Druschel CM, Woroniecki RP. Increased Prevalence of Renal and Urinary Tract Anomalies in Children with Conqenital Hypothyroidism. J Pediatr. 2009;154:263-266. [Abstract] / [Full Text] / [PDF]

10. De Felice M, Di Lauro R. Thyroid development and its disor ders: genetics and molecular mechanisms. Endocr Rev. 2004;25:722-746. [Abstract] / [Full Text] / [PDF]

11. Kratzsch J, Pulzer F. Thyroid gland development and defects. Best Pract Res Clin Endocrinol Metab. 2008;22:57-75. [Abstract] / [Full Text] / [PDF]

12. Péter $F$, Muzsnai A. Congenital disorders of the thyroid: hypo/hyper. Endocrinol Metab Clin North Am. 2009;38:491-507. [Abstract] / [Full Text] / [PDF]

13. Skuza KA, Sills IN, Stene M, Rapaport R. Prediction of neonatal hyperthyroidism in infants born to mothers with Graves disease. J Pediatr. 1996;128:264-268. [Abstract] / [Full Text] / [PDF]

14. Dussault JH, Coulombe P, Laberge C, Letarte J, Guyda H, Khoury K. Preliminary report on a mass screening program for neonatal hypothyroidism. J Pediatr. 1975;86:670-674. [Abstract] / [PDF]

15. Harris KB, Pass KA. Increase in congenital hypothyroidism in New York State and in the United States. Mol Genet Metab. 2007:91:268-277. [Abstract] / [Full Text] / [PDF] 
16. Lafranchi SH. Newborn screening strategies for congenital hypothyroidism: an update. J Inherit Metab Dis. 2010 doi: 10.1007/10545-010-9062-1. [Abstract] / [PDF]

17. Pass KA, Neto EC. Update: newborn screening for endocrinopathies. Endocrinol Metab Clin North Am. 2009;38:827-837. [Abstract] / [Full Text] / [PDF]

18. Van Tijn DA, de Vijlder JJ, Verbeeten B Jr, Verkerk PH, Vulsma T. Neonatal detection of congenital hypothyroidism of central origin. J Clin Endocrinol Metab. 2005;90:3350-3359. [Abstract] / [PDF]

19. Bongers-Schokking JJ, de Muinck Keizer-Schrama SM. Influence of timing and dose of thyroid hormone replacement on mental, psychomotor, and behavioral development in children with congenital hypothyroidism. J Pediatr. 2005;147:768-774. [Abstract] / [Full Text] / [PDF]

20. Selva KA, Harper A, Downs A, Blasco PA, Lafranchi SH. Neurodevelopmental outcomes in congenital hypothyroidism: comparison of initial T4 dose and time to reach target T4 and TSH. J Pediatr. 2005;147:775-780. [Abstract] / [Full Text] / [PDF]

21. Hanukoglu A, Perlman K, Shamis I, Brnjac L, Rovet J, Daneman D. Relationship of etiology to treatment in congenital hypothyroidism. J Clin Endocrinol Metab. 2001;86:186-191. [Abstract] / [Full Text] / [PDF]

22. Castanet M, Polak M, Bona"ti-Pellié C, Lyonnet $S$, Czernichow P, Léger J; AFDPHE (Association Française pour le Dépistage et la Prévention des Handicaps de l'Enfant). Nineteen years of national screening for congenital hypothyroidism: familial cases with thyroid dysgenesis suggest the involvement of genetic factors. J Clin Endocrinol Metab. 2001:86:200920-14. [Abstract] / [Full Text] / [PDF]

23. Castanet M, Marinovic D, Polak M, Léger J. Epidemiology of thyroid dysgenesis: the familial component. Horm Res Paediatr. 2010;73:231-237. [Abstract] / [Full Text] / [PDF]

24. Kempers MJ, van der Sluijs Veer L, Nijhuis-van der Sanden MW, Kooistra L, Wiedijk BM, Faber I, Last BF, de Vijlder JJ, Grootenhuis MA, Vulsma T. Intellectual and motor development of young adults with congenital hypothyroidism diagnosed by neonatal screening. J Clin Endocrinol Metab. 2006;91:418-424. [Abstract] / [PDF]

25. Salerno M, Oliviero U, Lettiero T, Guardasole V, Mattiacci DM, Saldamarco L, Capalbo D, Lucariello A, Saccà L, Cittadini A. Long-term cardiovascular effects of levothyroxine therapy in young adults with congenital hypothyroidism. J Clin Endocrino Metab. 2008;93:2486-2491. [Abstract] / [PDF]

26. Rapaport R, Sills I, Patel U, Oppenheimer E, Skuza K, Horlick M, Goldstein S, Dimartino J, Saenger P. Thyrotropin-releasing hormone stimulation tests in infants. J Clin Endocrinol Metab. 1993:77:889-894. [Abstract] / [PDF]

27. Daliva AL, Linder B, DiMartino-Nardi J, Saenger P. Three-year follow-up of borderline congenital hypothyroidism. J Pediatr. 2000;13:53-56. [Abstract] / [Full Text] / [PDF]

28. Rapaport R. Congenital hypothyroidism: expanding the spectrum. J Pediatr. 2000;136:10-12. [Full Text] / [PDF]

29. Leonardi D, Polizzotti N, Carta A, Gelsomino R, Sava L, Vigneri R, Calaciura F. Longitudinal study of thyroid function in children with mild hyperthyrotropinemia at neonatal screening for congenital hypothyroidism. J Clin Endocrinol Metab.2008;93:2679 2685. [Abstract] / [PDF]
30. Maruo Y, Takahashi H, Soeda I, Nishikura N, Matsui K, Ota Y, Mimura $Y$, Mori A, Sato H, Takeuchi Y. Transient congenital hypothyroidism caused by biallelic mutations of the dual oxidase 2 gene in Japanese patients detected by a neonatal screening program. J Clin Endocrinol Metab. 2008;93:4261-4267. [Abstract] / [Full Text] / [PDF]

31. Moreno JC, Bikker H, Kempers MJ, van Trotsenburg AS, Baas F, de Vijlder JJ, Vulsma T, Ris-Stalpers C. Inactivating mutations in the gene for thyroid oxidase 2 (THOX2) and congenital hypothyroidism. N Engl J Med. 2002;347:95-102. [Abstract] / [Full Text] / [PDF]

32. Van Tijn DA, De Vijlder JJ, Vulsma T. Role of the thyrotropinreleasing hormone stimulation test in diagnosis of congenital central hypothyroidism in infants. J Clin Endocrinol Metab. 2008:93:410-419. [Abstract] / [Full Text] / [PDF]

33. Paul DA, Leef KH, Stefano JL, Bartoshesky L. Low serum thyroxine on initial newborn screening is associated with intraventricular hemorrhage and death in very low birth weight infants. Pediatrics. 1998;101:903-907. [Abstract] / [Full Text] / [PDF]

34. Reuss ML, Leviton A, Paneth N, Susser M. Thyroxine values from newborn screening of 919 infants born before 29 weeks' gestation. Am J Public Health. 1997:87:1693-1697. [Full Text] / [PDF]

35. Chowdhry P, Scanlon JW, Auerbach R, Abbassi V. Results of controlled double-blind study of thyroid replacement in very low-birth-weight premature infants with hypothyroxinemia. Pediatrics. 1984;73:301-305. [Abstract] / [PDF]

36. Van Wassenaer AG, Kok JH, Briët JM, van Baar AL, de Vijlder JJ. Thyroid function in preterm newborns; is T4 treatment required in infants $<27$ weeks' gestational age? Exp Clin Endocrinol Diabetes. 1997:105:12-18. [Abstract]

37. Vanhole C, Aerssens P, Naulaers G, Casneuf A, Devlieger H, Van den Berghe G, de Zegher F. L-thyroxine treatment of preterm newborns: clinical and endocrine effects. Pediatr Res. 1997;42:87-92. [Abstract] / [Full Text]

38. Rapaport R, Rose SR, Freemark M. Hypothyroxinemia in the preterm infant: the benefits and risks of thyroxine treatment. $J$ Pediatr. 2001;139:182-188. [Abstract] / [Full Text] / [PDF]

39. Osborn DA, Hunt RW. Prophylactic postnatal thyroid hormones for prevention of morbidity and mortality in preterm infants. Cochrane Database Syst Rev. 2007:24:CD005948. [Abstract] [Full Text]

40. La Gamma EF, van Wassenaer AG, Ares S, Golombek SG, Kok JH, Quero J, Hong T, Rahbar MH, de Escobar GM, Fisher DA, Paneth $N$. Phase 1 trial of 4 thyroid hormone regimens for transient hypothyroxinemia in neonates of $<28$ weeks' gestation. Pediatrics. 2009;124:258-268. [Abstract] / [Full Text] / [PDF]

41. Rapaport R. Evaluation of thyroid status of infants in intensive care settings: recommended an extension of newborn screening. J Pediatr. 2003;143:556-558. [Full Text] / [PDF]

42. Hyman SJ, Greig F, Holzman I, Patel A, Wallach E, Rapapot R. Late rise of thyroid stimulating hormone in ill newborns. $J$ Pediatr Endocrinol Metab 2007;20:501-510. [Abstract] 